\title{
The Impact of Oil Rents on Subnational Development:
}

\author{
Evidence from Argentina
}

\author{
Lucas I. González \\ Escuela de Política y Gobierno, Universidad \\ Nacional de San Martín; Departamento de \\ Ciencias Políticas, Universidad Católica \\ Argentina \\ Consejo Nacional de Investigaciones \\ Científicas y Técnicas, CONICET \\ Buenos Aires, Argentina \\ lgonzalez@unsam.edu.ar
}

\author{
German Lodola \\ Departamento de Ciencia Política y \\ Estudios Internacionales \\ Universidad Torcuato Di Tella \\ Consejo Nacional de Investigaciones \\ Científicas y Técnicas, CONICET \\ Buenos Aires, Argentina \\ glodola@utdt.edu
}

\begin{abstract}
This article analyses the relation between mineral rents and development outcomes at the subnational level. The classical literature suggests that natural resource abundance has negative effects on well-being, a situation referred to as the resource curse. However, a novel strand of research emphasizes that rentier states worldwide exhibit contrasting outcomes. To account for such variation, this investigation aligns with approaches stressing the significance of contextual (place and institutional) factors to studying the resource curse. The main claim in this work is that both structural and institutional factors related to the extractive industry help account for variation in development outcomes. It contends that mineral rents are positively associated with human development and economic industrialization when the extractive sector is not geographically concentrated in enclave economies, and subnational fiscal institutions redistribute enough rents from producing to non-producing districts. It empirically tests this argument using a time series cross-sectional analysis, a difference-in-difference (DiD) estimation, and two case studies in Argentina, a country where subnational territorial units collect mineral royalties and have exogenously created their own rent-sharing regimes. It finally provides some comparative implications that may contribute to current debates on the socioeconomic impact of natural resource wealth.
\end{abstract}




\section{Introduction}

The classical literature on the effects of mineral (i.e., oil, gas, and mining) rents typically reports that natural resource abundance has negative economic and social effects, a situation referred to as the "resource curse" (Sachs and Warner 1995; Auty 1993; Gylfason et al. 1999; Davis and Tilton 2005). However, a novel strand of research has showed that rentier states worldwide exhibit contrasting outcomes. In this article, we claim that both structural and institutional factors related to the extractive industry and the distribution of rents help account for variation in the impact of mineral revenues on human development and economic industrialization.

Drawing on prior studies on unbalanced growth and economic rentierism, we first argue that the geographic concentration of the extractive sector in isolated enclave economies negatively affects social and economic well-being. This is so because enclaves generate limited backward and forward linkages to other sectors of the economy, except through the formal and informal channels of rents allocation (Hirschman 1977; Mahdavy 1970; Ross 1999; Dunning 2008). In addition, the enclave nature of production increases the costs of supplies and services relative to the costs in more integrated extractive economies. Finally, enclaves create opportunities for local incumbents to spend resource revenues in a more discretionary and particularistic way because they are less exposed to citizens' oversight, bureaucratic supervision, electoral challengers, and demands of organized interests such as trade unions than are they counterparts in economically integrated districts (Ross 2012; Gervasoni 2010; González 2018).

Second, following literature on redistributive politics and rentier spending (Bueno de Mesquita et al. 2003; Robinson et al. 2006; Remmer 2004; Rose 2012), we contend that rent- 
sharing regimes -or the fiscal institutions that allocate mineral income and assign spending powers among levels of government- have positive effects on development when they redistribute enough mineral revenues to both producing and non-producing districts.1 In particular, large redistribution have welfare-enhancing effects because rent-sharing arrangements have strings attached that constrain state incumbents' capacity to manipulate resource rents while, at the same time, demand local governments to spend a portion of them in providing collective goods. Furthermore, redistribution to lower levels of government shrinks state budgets and increases the fiscal independence of local incumbents to deliver public and private goods. As mayors -in particular those ruling competitive and non-enclave districts- are close in representation to their communities, they are exposed to social and political pressures demanding to spend part of these extraordinary revenues in the provision of public rather than private goods (Robinson et al. 2006). The fact that local districts receive mineral wealth increases their political value and the emergence of political challengers. The combination of societal demands and electoral contestation generate incentives for incumbents to claim credit for the non-particularistic allocation of rents. Conversely, limited redistribution concentrates access to large and unconstrained resources on the state government's disposal, which has strong incentives to build territorial power by overspending rents in patronage networks and placing local districts under subnational fiscal tutelage.

1 In a piece closely related to our concerns here, Díaz-Rioseco (2016) studies the political impact (i.e., level of political contestation) of these fiscal institutions in Argentina. 
Most empirical research aimed at providing evidence on the effects of natural resource abundance has overwhelmingly concentrated on single-country studies or cross-country comparisons. We adopt an innovative line of research and move beyond the country level of analysis to explore the impact of mineral rents on human development and economic industrialization using subnational variation. In doing so, we follow recent calls to explore within-country variation and conduct "place- and institution-sensitive research" to uncover how context matters (Orihuela 2017: 2). Methodologically, employing a subnational focus also allows us to keep constant a range of invariant factors, and several unobservable determinants that might also affect natural resource productivity and long-term economic growth (Snyder 2001; Goldberg et al. 2008: 488; Weitz-Shapiro 2012: 572).

We examine the effects of mineral rents, the geographic concentration of the extractive sector, and the distributive nature of rent-sharing institutions across subnational territorial units (provinces) in Argentina. This country constitutes an ideal ground for exploring these issues. First, it exhibits large subnational variation in mineral wealth across producing provinces as well as within them. Depending on a few geographic factors, this variation is exogenous to provincial characteristics. Second, because provinces levy royalties and enjoy high discretion over their use we can examine the consequences of mineral-related fiscal windfalls. Third, Argentina's robust federalism provides an additional source of territorial variation as each province is constitutionally allowed to determine its own rent-sharing regime. Some provinces grant large rents to either producing or all municipalities, whereas others distribute small fractions of them. As these institutions were established well before the period under analysis and remained highly stable throughout the years, we can treat them as exogenous to provincial development that varies over time. 
Using both a time-series cross-sectional analysis and a Difference-in-Difference (DiD) estimation, we document a slightly negative impact of mineral rents on subnational development, particularly in provinces where the extractive sector is geographically concentrated. Yet, we also substantiate significant improvements where rent-sharing institutions redistribute large amounts of mineral income across producing and nonproducing municipalities. Moreover, our DiD estimators show that exogenous oil windfalls improve industrialization -although not human development- in all provinces but more substantially in those with an integrated oil industry and redistributive fiscal rules. To illustrate some of the mechanisms behind these quantitative findings, we employ a diverse cases qualitative method (Seawright and Gerring 2008) by analyzing the provinces of Neuquén and Santa Cruz, which differ in their development outcomes and present extreme (high and low) values in our independent variables of interests.

\section{The Debate: A Curse of Natural Resources?}

The classical literature on natural resource abundance reports that mineral wealth promotes poor macroeconomic performance and unstable growth, a puzzle referred to as the "curse" of natural resources (for a review, see Van der Ploeg 2011). This research adopts a predominant national focus, conspicuously overlooking the study of such relations at the subnational level. However, the context of commodities boom in Latin America fostered a growing body of research that began to explore variation in the impact of mineral rents within countries (for a review, see Orihuela 2017). Most of these analyses document no or limited effects of resource wealth, reproducing a similar pattern observed in cross-national and single-country studies. 
For example, Caselli and Michaels (2013) find that oil production has only modest spillovers on local economic activity, as measured by non-oil GDP, in a cross-section sample of Brazilian municipalities. Although oil windfalls caused municipal revenues and spending on a variety of goods and services to increase, survey-based measures of transfers to households, infrastructure, education, and health show that increments were less (if at all) than the reported expenditure increase stemming from the windfall. Drawing on data from the media and the federal police, the authors conjecture that the primary reason why oil windfalls contribute little to local development is political corruption as alleged instances of mayors' illegal activities increase steadily in periods of large oil output. In a similar vein, using DiD estimation, Postali and Slaibe (2009) substantiate that changes introduced to the Brazilian revenue-sharing system, which began to disproportionally allocate resource rents to a subset of municipalities, did not foster economic growth in the receiver relative to the non-receiver districts.2

Similarly, Aragón and Rud (2009) find that Yanacocha, a Peruvian gold mine, has positive effects on local income and welfare at the household level. But such improvements were not driven by increased expenditure associated to the mining windfall but to an increase in demand for inputs only in the mine's supply market and surrounding areas. ArellanoYanguas (2016) demonstrates that rents transferred to several producing regions in Peru have a small effect on economic growth and are associated with higher poverty levels. Finally, Toscani (2017) reports that hydrocarbon discoveries in a sample of twenty-two

2 Yet Postali and Nishijima (2013) demonstrate that rents distributed under the new rules had positive impacts on illiteracy and access urban services. 
Latin American and Caribbean countries between 1980 and 2014 have a beneficial economic impact only in the short-run, as GDP picks up immediately after the discoveries but it dies down after a few years.

This literature has greatly contributed to understand regional socioeconomic disparities associated with variation in mineral wealth. To the best of our knowledge, however, there is no research on the subnational resource curse exploring how state-level structural and institutional factors distinctively affect the relation between mineral income and policy outcomes. Our central argument is that the geographical concentration of natural resource industries and the redistributive nature of subnational fiscal institutions correlate with development outcomes: the more/less concentration and the less/more redistribution, the worse/better development outcomes would be.

With regards to the role of structural factors, we assert that geographically concentrated extractive sectors negatively affect development, both at the local and provincial levels, through three analytically different but related mechanisms. First, enclave economies (selfcontained economies in which mineral production is developed in isolated and sparsely populated areas) promote limited linkages with other -particularly non-extractive- sectors of the economy (Hirschman 1977; Ross 2001, 2012: 44). Because mineral industries are extraordinarily capital-intensive and employ few (skilled) workers, only a minor portion of the population is directly engaged in the creation of wealth, while the majority is involved in the redistribution or utilization of rents (Beblawi and Luciani 1987: 51-52; Beblawi 1990; Luciani 1990; Karl 1997: 47; Dunning 2008: 23-114; Ross 2012: 45).

Second, considering the size and profitability of mineral activities, enclave economies increase the costs of economic sectors linked to the extractive industries, which demand 
specialized providers, supplies, and services that are usually located in urban centers thus increasing the cost of transportation and engineering. Furthermore, as enclave industries employ few workers with high salaries for short periods of time, they may generate positive spillovers in the enclave's local supplying market and minor businesses operating in the surrounding areas. However, such multiplier effects do not imply an increment in welfare province-wide. At best, enclaves promote backward -but not forward- linkages, while local authorities have few incentives to spend resources in the provision of collective goods that transitory workers do not demand and will not benefit from.

The third causal mechanism linking geographic concentration and poor development parallels the discussion on the resource curse, which stresses that dependence on mineral rents reduces social accountability. It does so fundamentally by creating opportunities for incumbents to design authoritarian policies aimed at buying support and repressing dissent (Ross 2001, 2012). We go further this canonical argument to assert that enclaves confront weak social demands and collective pressures for welfare redistribution because individuals, organized groups (trade unions), and opposition parties face high opportunity costs to demand and challenge incumbents. Trade unions have few workers and protesting is costly given the large distance from urban centers where contentious politics gains visibility, and opposition parties lack resources to contend and mobilize voters. In this environment, incumbents face little incentives to invest rents in credit claiming policies -which involve delivering public and semi-public goods- that may target broader social groups, foster economic activity, and boost tax revenue. On the contrary, they are prone to rely on their privileged fiscal position to finance traditional forms of particularism such as filling bureaucratic posts with core supporters. 
As for the explanatory role of institutional factors, we follow literature on government and rentier spending (Bueno de Mesquita et al. 2003; Robinson et al. 2006; Remmer 2004; Rodden 2002), and recent studies on the political effects of subnational fiscal institutions (Díaz-Rioseco 2016) to stress that rent-sharing regimes may in circumstances operate as politically built linkages with welfare-enhancing effects. First, when these arrangements divide mineral rents between provincial and municipal governments and distribute large amounts of them to producing and nonproducing districts, they shrink the size of provincial budgets and increase the fiscal autonomy of mayors from governors' largesse. In this scenario, state executives have fewer resources and capacity to spend rents in consolidating their territorial power financing a large state apparatus. Mayors, in turn, enjoy sizeable resources to deliver their own goods and programs. Facing increasing societal demands for non-particularistic spending and new electoral contenders who appreciate the political value of funded municipalities, mayors have incentives to claim credit for the provision of collective rather than private goods. Second, decentralized rent-sharing schemes also constrain incumbents' discretionary spending by compelling them to invest a considerable fraction of rents in delivering social services (especially in education and public health) and co-financing the execution of infrastructure projects.3 Conversely, when rent-sharing rules

3 The provision of public education and health in Argentina was decentralized to the provinces in the late 1970s and early 1990s. Although municipal governments are not in charge of delivering these services, they run basic health care centers and kindergartens, and play a key role in providing access to running water, waste collection, sanitation, and housing. In addition, mayors are crucial in pressuring provincial governments to build 
distribute few mineral rents to municipalities (or do it exclusively to producing districts) and centralize wealth in the provincial government, governors enjoy almost exclusive access to resources that can be spent in an unconstrained manner. These conditions, as rentier theorists predict (Rose 2012; Díaz-Rioseco 2016), reduce societal demands and increase barriers to entry the electoral market. Hence, limited redistribution fosters gubernatorial incentives to deploy rents in order to finance clientelism and patronage, which are mostly unrelated to socioeconomic development.

In sum, this study contributes to the debate on the resource curse in three important ways. First, extant literature has overwhelmingly pointed to the role played by the amount of mineral rents, the levels of production, and exogenous windfalls. Virtually no attention, however, has been paid to "contextual" variables that could also affect the relationship between mineral abundance and policy outcomes.4 By underscoring the centrality of subnational fiscal institutions and the structure of mineral production, we argue that different arrangements for the intergovernmental allocation of rents and the spatial organization of the extractive sector may hinder or, alternatively, promote socioeconomic

schools, health facilities, and urban infrastructure in their districts. During the national administrations of Néstor Kirchner and the first presidency of Cristina Fernández de Kirchner (2003-2011), the central government increased substantially the amount of investment in public works transferred to municipalities in an attempt to build territorial power with local leaders, bypassing governors (Lodola 2011: 222). Thus, mayors became involved in deciding how to spend some of these sizeable resources.

4 A notable exception is Díaz-Rioseco (2016). 
welfare. In doing so, this investigation aligns with approaches stressing the significance of contextual (place and institutional) factors to studying the resource curse (cf. Orihuela 2017). Second, we identify the mechanisms -economic linkages and incentives for incumbents to spend- connecting industrial management and fiscal regimes with subnational development. Third, in line with a growing consensus on mixed outcomes, we document the heterogeneous impact of mineral rents across regions within countries.

\section{Data and Methods}

To assess the impact of mineral rents, the geographical concentration of the extractive industries, and the provincial rent-sharing institutions on subnational development in Argentine, we begin by describing the variables of interest and the methodology employed in the empirical analysis.

We first estimate a pooled cross-sectional time-series regression model that considers the longitudinal nature of our data. We rely on ordinary least squares (OLS) with panel corrected and cluster standard errors to address problems of heteroscedasticity and autocorrelation. 5 A common approach in longitudinal analysis to deal with unobserved time invariant factors is to estimate a fixed-effects model. This estimator, however, is inefficient to deal with timeinvariant variables because of their high correlation with the fixed effects (Beck 2007;

5 The Breusch-Pagan/Cook-Weisberg test and a scatterplot for the error term indicate that there is heteroskedasticity, particularly in Model 2. The Wooldridge test reports autocorrelation in the panel data. The VIF indicates there is no serious collinearity among our key independent variables. 
Plumper and Troeger 2007; Wilson and Butler 2007). Both geographic concentration and rent-sharing regimes are time invariant in most provinces, so our models do not include fixed unit effects.6 Wald test rejects the suitability of using fixed effects in all regressions.

Our study focuses on two dependent variables. The first is a provincial Human Development Index (HDI) similar to that elaborated by the United Nations Development Program (UNDP). This index is a summary measure of average achievement in three dimensions: life expectancy at birth, adult literacy and combined primary, secondary, and tertiary enrollment, and gross income per capita. In contrast to UNDP reports that are only available for a few years, we created a measure that annually covers the entire period under analysis.7 The second dependent variable is a measure of provincial industrialization designed to capture the extent to which natural resource industries have spillovers on other, especially non-mineral, sectors. We use the gross industrial product (GIP), measured as the share of the provincial gross geographic product (GGP).

The main independent variable, mineral rents, is measured in annual per capita dollars of oil, gas, and mining royalties collected and administered by each province.8 The 1994

6 The inclusion of fixed effects also reduces degrees of freedom, which is particularly sensible in small panel data like that used in this article.

7 These data are from the National Institute of Statistics and Censuses (INDEC) and cover the 1996-2010 period.

8 Data for the 1993-2013 period were made available by the Directorate for the Analysis of Public Expenditure and Social Programs, and the National Direction for Fiscal Coordination with the Provinces, Ministry of Economy. 
Constitution establishes that provinces enjoy property over natural resources (what is called as the "original domain") located in their territories (article 124).9 This means that they administer royalties collected from mineral activities and have complete discretion over how these resources can be spent. Indeed, the only institutional constrain is set by their respective revenue-sharing systems which mandate a percentage -if any- of mineral revenues to be shared with municipalities.

Quantitative research on rentierism has operationalized mineral rents in different ways. Some analysts rely on countries' (provinces') dependence on natural resource income, such as mineral production or exports as a share of the GDP. Others draw upon countries' (provinces') fiscal reliance on these revenues. Both measures, however, are ill suited to tackle our primary concern here: the territorial redistribution of resource wealth and its spending effects on development. While mineral dependence accounts for the relative importance of the extractive sector, data on fiscal reliance measure the degree to which natural resource activities are taxed (not spent) by public budgets (Díaz-Rioseco 2016:

9 Congress, though, regulates royalties through specific laws. The Hydrocarbons Law, enacted in 1967, and its 2014 amendments (Law 27,007) establish that concessionaires should pay monthly rents to the provinces up to 12 percent of the hydrocarbons extracted at the wellhead. The federal government can reduce this amount up to 5 percent depending on productivity. 
1946).10 Thus, because provinces are constitutionally entitled to gather and use resource revenues, we can treat flows of mineral rents as provincial fiscal windfalls.

There is enormous provincial variation in mineral revenues.11 It ranges from 0 to 1,582 per capita dollars, with a mean of 117 and a standard deviation of 268. Figure 1 shows the average per capita mineral rents collected by each province between 1983 and 2013. As it can be seen, a group of six jurisdictions (Tierra del Fuego, Santa Cruz, Neuquén, Chubut, Río Negro, and Mendoza) received substantial resource revenues, a second group (La Pampa, Salta, Catamarca, Entre Ríos, and San Juan) obtained modest amounts, and the rest either received very little or no mineral income.

${ }_{10}$ Furthermore, measuring mineral rents by flows of resource exports is an outcome variable in its own right, and therefore not completely exogenous (Dunning 2008). 11 Official data in Argentina do not distinguish among different sources of mineral rents. This limitation, however, is not a major concern here because mining provinces are not oil and gas producers, and hydrocarbon provinces have marginal mining sectors, except for Santa Cruz, where mining represents 15 percent of total revenues (CAEM 2015). 
Figure 1: Minerals Rents Across Provinces (per capita dollars, 1983-2013)



Source: Directorate for the Analysis of Public Expenditure and Social Programs, and National Direction for Fiscal Coordination with the Provinces, Ministry of Economy.

We introduce two independent variables to test the argument that the geographical concentration of the extractive sector negatively correlates with provincial HDI and industrialization. We utilize the distance (in kilometers) between the main producing area and the provincial capital (or the most populated city in the province). Distance ranges from over $700 \mathrm{~km}$ in Santa Cruz to about $100 \mathrm{~km}$ in Neuquén, with a mean of 398 and a standard deviation of $187 \mathrm{~km}$. We also use the size of employment in the mineral sector as a share of the total provincial employment. Extractive industries employ a varied share of the labor 
force: 7.4 percent on average, ranging from 20 percent in Santa Cruz to 1.2 in Rio Negro, with a standard deviation of 5.8 .

In order to measure the redistributive effect of rent-sharing institutions, we created an index that computes the share of mineral revenues legally allocated by the provincial government to all municipalities weighted by the percentage of these rents exclusively distributed to the producing districts. For example, Neuquén distributes 15 percent of natural revenues to all municipalities. From this value, 10 percent is exclusively allocated to producing districts. Therefore, Neuquén receives a score of 13.5 which results from computing 90 percent (rents received by nonproducing municipalities) of the 15 percent distributed to all districts. When a province only allocates rents to producing regions, we impute a score of 1 . Provinces with no rent-sharing institutions are coded as 0 . The index thus ranges from a minimum of 1 to a maximum of 20 among producing provinces, with a mean of 9.6 and a standard deviation of 6 . We include all types of mineral rents allocated to municipalities -conditional and discretional, unearmarked and with strings- because we argue that their potential effects on development primarily result from the fact that local incumbents can spend these resources in a constrained or unconstrained manner. That is, mayors appreciate security in reception over discretion because they often enjoy some choice over the allocated rents, whereas the impact of discretion in the absence of rents is null (Bonvecchi and Lodola 2011: 186). Furthermore, earmarked rents typically mandate municipalities to spend a percentage of mineral revenues in policy areas, notably education and health, which directly affect provincial human development. 
The regression models also include the level of provincial political competition based on the effective number of competitive parties in the previous gubernatorial election.12 We incorporate this variable because a strand of literature claims that lack of political competition (and the certainty of electoral results) create incentives for politicians to secure their core supporters by spending public resources on targeted particularistic goods. In contrast, larger electoral coalitions on which incumbents depend to remain in office are associated to the provision of collective goods as they target broader audiences (Bueno de Mesquita et al. 2003; Robinson et al. 2006; Magaloni et al. 2007). In a similar vein, some scholars argue that an increase in party competition fosters social spending because it reduces incumbents' ability to use public resources in order to further their own political agenda, increases monitoring by the political opposition, and makes the threat of being replaced from office more credible (Grzymala-Busse 2007; see also Weitz-Shapiro 2012: 570). Our measure of competition ranges from 1.5 to 10 , with a mean of 3.1 and a standard deviation of 1.1.

All models also control for national GDP growth, provincial population, and per capita non-mineral transfers from the central government to the provinces. We expect national economic growth to be positively correlated with provincial HDI and industrialization.

12 Our variable of political competition highly correlates with both the opposition share of the votes and the margin of victory in state executive contests. So that our results do not change if we employ these indicators. We also run alternative models including a dummy variable to capture president-governor political alignment. This variable never reaches statistical significance while the main results remain unchanged. 
Population should be negatively signed because incumbents typically face more spending restrictions in larger jurisdictions. Finally, intergovernmental transfers are expected to be positively associated with development outcomes. The reason lies, first, on the fact that a substantial amount of these funds -especially, those related to housing, electrification, and urban infrastructure- have strings attached and some relatively effective monitoring from the central government (Bonvecchi and Lodola 2011). Moreover, as the bulk of these transfers are unearmarked, and so automatically increase provincial budgets, governors have ample discretion to use part of them to target social and material needs.

In addition to regression analysis, we use a classical DiD approach to identify the causal effect of mineral rents, which are largely dependent on external windfalls, on provincial HDI and GIP. We observe the average performance of two groups of provinces in two time periods: before and after the oil boom (1999-2003) that exogenously increased mineral revenues.13 We create three different sets of comparisons: a) provinces with high versus low (defined as above and below the mean values, respectively) oil and gas employment, b) provinces with low versus high geographical concentration of the extractive sector; and c) provinces with highly versus poorly redistributive rent-sharing institutions. We also compare outcomes for the treatment groups with provinces that do not have mineral production -and hence do not receive rents- under the expectation that these jurisdictions will not be affected by oil windfalls (Gertler et al. 2016: 142).

13 Mineral rents more than tripled in producing provinces, skyrocketing from an average of 11 percent of the provincial budget in 1998 to 36 percent in 2002 . 


\section{Quantitative Analysis: Regression and DiD Results}

Results from two identical specifications of a time series cross-sectional regression model, one for each dependent variable, are reported in Table 1. In general, estimates support our theoretical expectations. First, holding other variables constant, mineral rents have a modest negative impact on provincial human development and industrialization. Substantively, an increment in rents of 10 dollars per capita is associated with a decrease of .001 points in the HDI, and a decrease of .13 percent in the GIP. This result lends some credit to our argument that mineral rents are detrimental for development when the extractive industry is concentrated and rent-sharing regimes concentrates mineral revenues in the provincial government.

Second, the coefficients of geographical concentration also tend to perform as expected as they are negatively signed and statistically significant at the .01 level. Substantively, a 100 $\mathrm{km}$ increase in the distance from the extractive industrial pole to the most populated city in the province reduces HDI and GIP in 0.01 points and 1.6 percent, respectively. In the same line, the coefficient for mineral employment, a reasonable proxy of the degree to which mineral activities generate linkages with other economic sectors, is often positive and statistically significant at the .01 level. Holding all other variables constant, a 1 percent increase in mineral employment is associated with .05 points increment in HDI and 1.4 percent increase in GIP. Third, the coefficient of the variable capturing the redistributive component of rent-sharing institutions positively correlates with human development -an increment in one standard deviation in revenue-sharing improves HDI in .05 points, which is near half of that standard deviation- but it surprisingly does not seem to be associated with industrialization. 
Finally, we find that neither political competition nor the volume of federal transfers correlate with HDI or GIP (see also González 2014: 186-188), while national economic growth is only positively associated with industrialization. 
Table 1: Regression Results

\begin{tabular}{|l|c|c|}
\hline \multicolumn{1}{|c|}{ Variables } & $\begin{array}{c}\text { Model 1 } \\
\text { HDI }\end{array}$ & $\begin{array}{c}\text { Model 2 } \\
\text { GIP }\end{array}$ \\
\hline Oil Rents per capita & $-0.000^{* * *}$ & $-0.013^{* * *}$ \\
& $0.000)$ & $(0.002)$ \\
\hline Oil Employment & $0.050^{* * *}$ & $1.357^{* * *}$ \\
(nat. log.) & $(0.004)$ & $(0.234)$ \\
\hline Distance & $-0.000^{* * *}$ & $-0.016^{* * *}$ \\
& $(0.000)$ & $(0.001)$ \\
\hline Rents Sharing & $0.010^{* * *}$ & 0.214 \\
Regime & $(0.001)$ & $(0.215)$ \\
\hline Total Federal & -0.022 & 0.113 \\
Transfers per capita & $(0.016)$ & $(0.473)$ \\
(nat. log.) & & \\
\hline National GDP & 0.000 & 0.046 \\
Growth & $(0.002)$ & $(0.019)$ \\
\hline Effective Number of & 0.029 & 0.983 \\
Parties (nat. log.) & $0.020)$ & $(1.161)$ \\
\hline Provincial & $-0.023^{* * *}$ & $-0.396^{* * *}$ \\
Population (nat. log.) & $(0.008)$ & $(0.383)$ \\
\hline Constant & $0.886^{* * *}$ & $21.433^{* * *}$ \\
& $(0.103)$ & $(5.669)$ \\
\hline Observations & 316 & 297 \\
\hline R2 & 0.52 & 0.20 \\
\hline Cross-sectional units & 24 & 24 \\
\hline
\end{tabular}

Dependent Variables: Human Development Index; Gross Industrial Product. Unstandardized regression coefficients. Panel Corrected Standard Errors reported in parenthesis. ${ }^{* * *} \mathrm{p}<0.01$ 
To provide additional empirical evidence in support of our argument, we make use of the international oil shock experienced in Argentine between 1999 and 2003. We perform a DiD estimation that provides unbiased treatment effect estimates when, in the absence of a treatment, the average outcomes for the treated and control groups would have followed parallel trends over time. Our assumption is that this windfall is indeed exogenous to provincial characteristics and policies regarding the oil sector. Thus, we expect the oil boom to generate positive impacts in hydrocarbon provinces relative to non-producing jurisdictions, and especially where the extractive sector is geographically integrated and rent-sharing institutions decentralize the allocation of rents to municipalities.

Table 2 displays the results of a DiD estimation in which the treatment and control groups are composed by producing provinces with comparatively high and low levels of oil-and-gas employment, respectively. As it can be appreciated, both groups perform similarly before the external oil shock in terms of HDI, while provinces in the control group had an almost tenpercentage point larger GIP. After the oil boom, HDI and GIP increased marginally in the treatment group relative to the control group (.014 points and .5 percent), but these differences are statistically undistinguishable from zero. To check these results, we performed an alternative comparison between producing provinces with high oil-and-gas employment (treatment group) and non-producing provinces (control group). Differences in HDI and GIP after the oil windfall are lower than in the previous comparison (.008 points and 4.1 percent, respectively) and, again, not statistically significant at any reasonable level of confidence. 
Table 2: Difference-in-Difference Estimation using Oil Employment

\begin{tabular}{|c|c|c|c|}
\hline \multicolumn{2}{|c|}{ Variables } & HDI & GIP \\
\hline \multirow{3}{*}{ Before } & Control & 0.726 & 15.248 \\
\hline & Treated & 0.694 & 5.461 \\
\hline & Diff $(T-C)$ & $\begin{array}{c}-0.031 \\
(0.027)\end{array}$ & $\begin{array}{l}-9.787^{* * *} \\
(1.497)\end{array}$ \\
\hline \multirow{3}{*}{ After } & Control & 0.692 & 17.357 \\
\hline & Treated & 0.675 & 8.071 \\
\hline & Diff $(T-C)$ & $\begin{array}{l}-0.017 \\
(0.027)\end{array}$ & $\begin{array}{l}-9.286^{* * *} \\
(1.658)\end{array}$ \\
\hline \multicolumn{2}{|c|}{ Diff-in-Diff } & $\begin{array}{c}0.014 \\
(0.038)\end{array}$ & $\begin{array}{c}0.501 \\
(2.234)\end{array}$ \\
\hline
\end{tabular}

Dependent Variables: Human Development Index; Gross Industrial Product. Standard Errors reported in parenthesis. ${ }^{* * *} \mathrm{p}<0.01$

Table 3 displays the results of a second DiD estimation using our two most relevant independent variables. The treatment group is now composed by provinces with short geographic distance (below the mean) and highly redistributive (above the mean) rentsharing institutions. The control group is formed by provinces with these values above and below the mean, respectively. The estimators indicate that after the sharp increase in oil prices, HDI is not statistically different in the treatment and control groups. But whereas GIP before the oil boom was 6 percent lower in the treatment compared to the control group, it augmented by 7.9 percent in the former relative to the latter group of provinces after the windfall. As a further control, it is worth noting that when we compare jurisdictions with 
territorially integrated extractive sectors and redistributive institutions in the treatment group versus non-producing provinces in the control, the difference in HDI continues to be marginal and statistically insignificant while GIP increased by a significant 9.9 percent in hydrocarbon provinces after the oil shock.

Table 3: Difference-in-Difference Estimation using Geographic Distance and RentSharing Institutions

\begin{tabular}{|c|c|c|c|}
\hline \multicolumn{2}{|c|}{ Variables } & HDI & GIP \\
\hline \multirow{3}{*}{ Before } & Control & 0.655 & 10.982 \\
\hline & Treated & 0.820 & 4.848 \\
\hline & Diff $(T-C)$ & $\begin{array}{l}0.165^{* * *} \\
(0.016)\end{array}$ & $\begin{array}{l}-6.134^{* *} \\
(2.365)\end{array}$ \\
\hline \multirow{3}{*}{ After } & Control & 0.636 & 11.570 \\
\hline & Treated & 0.780 & 13.300 \\
\hline & Diff (T-C) & $\begin{array}{l}0.144^{* * *} \\
(0.016)\end{array}$ & $\begin{array}{c}1.730 \\
(2.235)\end{array}$ \\
\hline \multicolumn{2}{|c|}{ Diff-in-Diff } & $\begin{array}{c}-0.021 \\
(0.022)\end{array}$ & $\begin{array}{c}7.864^{* *} \\
(3.254)\end{array}$ \\
\hline
\end{tabular}

Dependent Variables: Human Development Index; Gross Industrial Product. Standard Errors reported in parenthesis. ${ }^{* *} \mathrm{p}<0.05 ;{ }^{* * *} \mathrm{p}<0.01$

In sum, results of our DiD estimations document that in scenarios of large fiscal windfalls integrated extractive industries and redistributive fiscal institutions have higher positive effects on subnational development than oil-and-gas employment. As one may expect, the 
impact is modest on social welfare outcomes, particularly in slow-changing indicators such as life expectancy and illiteracy rates, but substantial on industrialization. Modest improvements in HDI may also result from the fact that producing provinces (especially, those in the Patagonia) performed considerably well in social indicators before the oil windfall, whereas some of the non-hydrocarbon producing provinces (in particular, those in the Pampas) favored from the 2000s agriculture commodities boom.

\section{Qualitative Analysis: Two Diverse Cases}

In this section, we illustrate some of the mechanisms behind our quantitative findings by analyzing two otherwise similar provinces, Santa Cruz and Neuquén, that exhibit different development outcomes while sharply differ in the territorial organization of the extractive sector and the redistributive nature of their rent-sharing regimes. Methodologically, we employ a "diverse cases" selection technique (Seawright and Gerring 2008) whose primary objective is to choose cases that achieve the maximum variance along theoretically relevant dimensions. The selected provinces, thus, have extreme values -high and low- in our two independent variables of interest. Santa Cruz, our low (negative) case, produces most of its oil in isolated enclaves and its rent-sharing institutions redistributes very little resource revenues to municipalities. In contrast, Neuquén, our high (positive) case, has an integrated oil sector while its fiscal regime allocates a large share of mineral rents to local governments.

At the same time, Neuquén and Santa Cruz present a number of similarities that allow for controls on our main argument. The first commonality is that both jurisdictions collect, on average, an analogous proportion of mineral revenues in the period: 39 and 32 percent of their current income, respectively. The second is that the mineral sector has a similar 
relevance in the labor market, accounting for almost 14 percent of private employment (Kofman and López Crespo 2018). These similarities suggest that variation in development outcomes cannot be attributable to the relative size of the extractive industry. The third is that since the return of democracy these provinces have been governed by a single party without alternation: the local Movimiento Popular Neuquino, and the Peronist party. Both are highly factionalized parties that have been able to develop tight control of the public administration. The fourth and final commonality refers to the structure of government as Santa Cruz and Neuquén have similar two-tiered political structures, with autonomous municipalities organized at the department level.14 This is an important element of coordination, as subnational policies are highly affected by the type (and number) of municipal units.

In terms of our dependent variables, both provincial jurisdictions have comparatively high levels of HDI, at least for Argentina's standards. However, HDI is significantly lower (about 15 percent) in Santa Cruz, despite it has about half of Neuquén's population. The average HDI values for these provinces during the period under study (1996-2010) are 68 and .77 points respectively, ranging from .59 to .73 in Santa Cruz and from .71 and .81 in

14 Neuquén, however, doubles Santa Cruz in the number of municipalities: 35 versus 15. It also organizes municipalities in three categories according to their population. Only those in the first category enact their own constitutions, while those in the third do not elect mayors but a gubernatorial council. The three of them have the same constrains over the use of mineral revenues transferred from the provincial government. 
Neuquén.15 In addition, both exhibit a markedly different performance of industrialization, as measured by the share of the provincial GGP produced by industrial firms between 1993 and 2013. Whereas in Santa Cruz the GIP averages 2.6 percent with a maximum of 3.4, in Neuquén it reaches an average of 4.7 and a highest value of 9.2 percent. In the discussion that follows we show how limited redistribution and the existence of resource enclaves not only negatively influences the welfare-enhancing effects of mineral rents province-wide, but also in the enclaves. Likewise, positive effects of large redistribution and integrated producing areas are observed at both the provincial and municipal levels.

\section{Santa Cruz: Enclave Production and Limited Redistribution}

The province of Santa Cruz is the second largest oil and the fourth gas producer jurisdiction, with close to 22 and 10 percent of Argentina's production, respectively. Almost 90 percent of petroleum and 50 percent of gas is extracted in the Gulf of San Jorge basin, particularly in the remote enclave towns of Las Heras, Pico Truncado, and Cañadón Seco, located in the Patagonian steppe, about $750 \mathrm{~km}$ away from the province's capital city.

15 On average, life expectancy at birth in Santa Cruz is around two years lower than in Neuquén (74.1 versus 76.3), with the difference increasing after the oil boom in almost one year. Gross income per capita (in dollars) is also consistently lower (around 40 percent) in Santa Cruz. However, this province performs slightly better in adult literacy (98.8 versus 97.4 percent), and education enrollment (95.8 versus 94.6 percent), mainly due to higher dropout at secondary school in Neuquén. It is worth noting that after the oil windfall school enrollment improved in Neuquén proportionally more than it did it in Santa Cruz. 
Because this is a mature oil zone that began operating in the mid-1960s, production depends on investments in pulling activities (especially, secondary recovery through waterflooding) and drilling for new wells. There are no refineries in Santa Cruz, so most crude is exported or transported to be refined in the provinces of Buenos Aires and Santa Fe. In the last decades, three major companies have operated in the area: Argentina's state-run energy producer YPF (former Repsol), and the private firms Sinopec and Pan American Energy, accounting for almost 60, 25, and 10 percent of oil production respectively (IPP 2018: 22).16

The enclave structure of the hydrocarbon sector has promoted few forward linkages to the province's industrial and service sectors. The GIP as a share of the GGP in Santa Cruz marginally increased at an annual average rate of 0.06 percent during the years under scrutiny, while the share of the service sector augmented even less, at 0.007 percent. This path is confirmed by a DiD estimation, similar to that presented in Table 3, in which we test the impact of the 1999-2003 oil boom, but using only Santa Cruz in the treatment group and the other producing provinces in the control group. As expected, neither the GIP nor the share of the GGP represented by the service sector are statistically different in both groups.

Furthermore, Santa Cruz's rent-sharing regime is the least redistributive of all provincial regimes. It only allocates 7 percent of mineral revenues to municipalities, while the rest of the producing provinces average 10.12 percent. Consequently, fiscal institutions grant the provincial government quasi-monopoly access to mineral rents. These revenues, as all

16 Natural gas, which is transported through pipelines to Chile and Argentina's central region, is exploited by YPF (25 percent), and the private firms Compañía General de Combustibles (27), Sinopec (21), and Enap Sipetrol (13). 
income collected and all debt taken by the province, are kept centralized in a single current bank account (the Sistema de Cuenta Unica de Tesoro) that is administered by the provincial treasury office. By means of this instrument, the government can allocate rents with little oversight from the legislature and other control institutions such as the Court of Auditors (in which the party of the governor has a majority).

To a large extent, mineral rents serve to finance employment in the public sector, mostly in the province's capital where resides 35 percent of the population. In the time frame covered in this article, Santa Cruz is the third province with the largest share of public employment as a share of total formal employment (51.6 percent), and the mineraldependent jurisdiction with the worst ratio (1.4) of public versus private employment. Indeed, between 1993 and 2013 public employment increased from 80 workers every 1,000 inhabitants to 110 , equivalent to a 38 percent. The increment in the rest of the country during the same period was from 51 to 67 workers, or 31 percent. For that reason, current spending as a share of total government spending in Santa Cruz almost doubled, augmenting from 55.4 to 91.3 percent, while capital expenditures dramatically decreased from 44.6 to 8.7 percent.

The negative impact of resource industry territorial concentration and rent-sharing centralization on the welfare-improving effects of mineral revenues are also evident in the 
producing districts. The case of Las Heras, a small city of around 20,000 people that has been growing as an oil enclave since the early 1970s, is illustrative.17

Las Heras generates approximately 65 percent of Santa Cruz's oil production but few resource rents are reinvested in the area. According to the latest data available (September 2017 ), the provincial government collected about $\$ 678$ per capita in oil revenues, but only a small share of it is allocated to Las Heras: \$53.5 per capita (Ministerio de Economía de Santa Cruz, 2018). Most of the people in town work in the oil economy, by far the most important activity in the region. Salaries in the oil sector are comparatively high: a wellhead operator, who is a relatively low-skilled worker, earns about 4,400 dollars per month, almost seven times the salary in the provincial public sector. But only a small part of these earnings is spent in Las Heras as many oil workers are non-native, temporary residents who send part of their salaries home. The city has a meager and disorganized industrial sector composed by a small number of familiar firms and local businesses that employ few people and are scarcely integrated to the hydrocarbon industry (IADB-FYPF 2014a: 91).18 The service sector (hotels and restaurants) is of poor quality and expensive for national standards. The city also lacks a public transportation system, which causes serious communication problems (IADB-FYPF 2014b: 89).

17 Unfortunately, there are not data on HDI at the municipal level in Argentina. We employ welfare data on producing areas - e.g., urban infrastructure, poverty, housing — that can arguably be considered factors connected to the welfare indicators in the HDI. 18 The other economic activities, which are not adequately modernized and contribute little to the region's economic output, are sheep and goat livestock, wool, and tourism. 
Las Heras has a high housing deficit, 41.4 percent in 2013, compared to the capital city, Rio Gallegos (6.3 in 2010), and very high informality of property domains (27 percent) due to a large process of informal occupation of land in the city. In addition, 12 percent of homes have serious deficits in terms of basic habitability standards (IADB-FYPF 2014b, 87-88). There are also serious deficits in the provision of health care and public education. Indeed, there is only one hospital in Las Heras that lacks many specialized services and cannot deal with the increasing demand due to the growth of urban population, and three health posts to cover the rural areas (IADB-FYPF 2014a: 98).19 Public schools suffer from overpopulation and high teacher turnover stemming from severe housing deficits, lack of a public transportation system, and low salaries that do not contemplate high transportation costs to travel long distances. Although 99 percent of children between 6 and 15 years old attend school, enrolment is only 66 percent for the age 16-19, when in the provincial capital is close to 90 percent (IADB-FYPF 2014a: 94-97; INDEC 2001, 2010). In addition, Las Heras has no university education, which produces high migration of young people.

With a modest budget and large social needs, the municipal government allocates most resource income to current expenditures, particularly to pay salaries in the local public sector, whereas resources to finance public works and infrastructure projects come almost exclusively from the federal administration (IADB-FYPF 2014b: 101).

19 Population grew at an annual rate of 5.5 percent between 1970 and 2010, and 7.5 percent since then. 


\section{Neuquén: Integrated Production and Large Redistribution}

The province of Neuquén ranks first and third in the production of gas and oil, with approximately 43 and 20 percent of the country's production, respectively. Since its beginning in the early 1920s, the hydrocarbon industry adopted an integrating structure as most natural resources are extracted and transformed in geographic corridors connecting $100 \mathrm{~km}$ North and West the province's capital to the producing cities of Cutral Có, Plaza Huincul, and Añelo. This geographic distribution of the resource industry contributed to the establishment of an industrial center, including several mayor hydrocarbon companies, oil refineries, as well as small and medium size firms that provide supplies and services to extractive activities. Among the large firms, YPF concentrates about 35 percent of petroleum production, while private firms such as Chevron, Petrobras, and Pluspetrol, account for 14, 13 , and 10 percent, respectively.

In addition, Neuquén's rent-sharing institutions distribute 15 percent of mineral income to municipalities, more than double of the share allocated by Santa Cruz's. So that, for instance, Añelo receives five times the amount of per capita rents that Las Heras gets. These funds are reinvested across the province to improve welfare indicators as well as to promote basic infrastructure to other economic activities. In the particular case of Añelo's municipal budget, 26 per cent of current revenues are collected at the local level, while 73 per cent come from federal and provincial transfers (44 per cent are funds used to cover the local deficit and 66 per cent correspond to provincial revenue sharing funds). Of the total budget, 67 percent is allocated into current expenditures and 33 percent to capital expenditures (IADB-FYPF 2014a: 77-78). 
The state legislation not only reduces the provincial budget but also limits gubernatorial latitude over the use of resource revenues by explicitly incorporating the participation of both an intergovernmental (municipal-provincial) committee and the provincial legislature in the process of fund allocation. Thus, the provincial government has less capacity to control financially dependent municipalities and spur the political support of mayors.

The non-enclave nature of mineral production and the decentralization of resource rents to local governments explain, at least in part, why Neuquén's GIP increased at a yearly average rate five times higher than in Santa Cruz, and the share of the service sector augmented 150 times more than in Santa Cruz. Interestingly, if we estimate the DiD in Table 3 including only Neuquén in the treatment group, there is a statistically significant difference in both the GIP and the share of the service sector of 4 and 12.5 percent after the oil windfall in the treated province relative to the non-treated group. In contrast to Santa Cruz's spending pattern, the scenario of booming international oil prices fostered increments in capital and reductions in personnel spending, from 51.3 percent of the budget in 2001 to 37.5 in 2004. Thus, public employment as a share of the total private employment diminished almost 16 percentage points, and the provincial administration did not expand, as rentier theories would predict, but rather witnessed a vegetative annual growth of 1.7 percent (Gonzalez 2018: 112).

Neuquén is experiencing a strong economic boost as a consequence of large investments in the hydrocarbon sector. This economic growth created jobs that attracted new population and has fostered the development of the industrial and services sector (IADB-FYPF 2014a: 24). The hydrocarbon production in the Vaca Muerta shale oil fields led to the creation of 5,000 jobs in Neuquén, of which, Añelo absorbed about 20 percent (IADB-FYPF 2014a: 69). 
The entire oil and gas sector generated a total of 57,253 jobs in the province $(14,109$ direct and the rest indirect and induced) (IADB-FYPF 2014a: 20; IAPG, 2014), compared to only 1,831 in Santa Cruz (during 2013, IADB-FYPF 2014b: 53).

More jobs, larger and more active unions, and closer distance to large urban and political centers also mean more societal demands and pressures on politicians. Neuquén systematically ranked as one of the most socially conflictive and mobilized provinces in Argentina during 2009-2017 (data available for this period). Public sector unions conducted about 50 percent of all protests, and about 20 percent of them are in charge of private sector unions, including those in the oil sector (Observatorio Económico ACIPAN 2013-2017; Diagnóstico Político 2009-2016).

Differently from Las Heras, local politicians in Añelo have a larger local budget to target local social needs and demands for infrastructure and face more societal and sectorial pressures to deliver public goods and services.20 All this impacted on better welfare standards in the city and its region, despite its enormous population growth (Añelo's population skyrocketed from 1,742 inhabitants in 2001 to 6,000 in 2015).

The housing deficit in Añelo is 27 per cent according to the 2010 census (compared to 41.4 percent in Las Heras in 2013) (IADB-FYPF 2014a: 66). But its municipality granted pieces of land for 180 social housing units and plans to grant 370 more to cover it (IADBFYPF 2014a: 67).

20 Añelo's mayor, Darío Díaz, confirmed these sectoral and citizens' pressures for more and better public services in town (Interview, April 2016). 
Health and education services are also limited. There is only one health center in the city, and it does not have the equipment, infrastructure or personnel to attend most of the specialties, including pediatrics (IADB-FYPF 2014a: 24). The current educational offer is exclusively public: there is 1 kindergarten, 2 primary schools, and 1 secondary school (IADBFYPF 2014a: 70). But the main difference with Las Heras is that there is a great variety of complex health services in the nearby city of Neuquén, as well as tertiary institutes and technical schools in nearby towns, including two national public universities within $100 \mathrm{~km}$ (IADB-FYPF 2014a: 71).

In sum, oil towns in Neuquén, particularly Añelo, have redistributed a larger share of their wealth to the rest of the province and developed more economic linkages with other large cities in the region. This is very different to what happened in Las Heras, where oil rents are concentrated in a distant and quite socially isolated administrative center. As a result, these oil towns in Neuquén helped enlarging the industrial and service sectors and their oil wealth contributed to improve welfare indicators across the province.

\section{Final Comments}

This article has developed and empirically tested an argument on the impact of mineral rents on subnational socioeconomic development in a highly decentralized federal country, where provinces are constitutionally allowed to collect and administer mineral royalties and have exogenously created fiscal institutions to distribute these rents to municipalities. We argued that both structural and institutional factors related to the extractive sector affect policy outcomes province-wide by influencing the sharing of extraordinary rents across economic sectors and local governments. 
Relying on a mixed method strategy that combines quantitative and qualitative research, we first documented that the geographic concentration of the extractive industry in enclave economies negatively correlates with human capital and industrialization. This is so, we claim, because enclaves generate limited backward and forward linkages with other sectors of the economy, increase productivity costs, and create strong incentives for municipal mayors to overspend rents in non-programmatic (particularistic) expenditures as they are less exposed to citizens' oversight, bureaucratic supervision, and pressures from organized social groups and political challengers than typically are their counterparts in more urban districts. Second, we asserted that rent-sharing regimes positively correlates with provincial development when they redistribute enough amounts of rents to both producing and nonproducing municipal districts. This is primarily so because rent-sharing institutions usually have strings attached mandating local incumbents to allocate a fraction of the mineral revenues transferred by the provincial government to social service spending. In addition, by augmenting the financial autonomy of local governments, more redistributive rules also increase social pressures for the provision of collective (semi-public and public) rather than private goods. When minerals are produced in enclaves and rents are not redistributed, only the economic sectors closely related to the extractive activities and the central government collecting rents tend to reap the benefits of natural resources wealth.

In identifying the conditions under which mineral rents may foster or hinder positive economic and social outcomes, this article contributes to understand some contradictory findings reported in previous research, which has almost exclusively focused on the role played by amounts of mineral rents and production. Furthermore, our findings have comparative implications for other developing democracies that possess substantial natural 
resources. Although politicians in these countries may not have control over how mineral production is geographically organized (enclaves or more integrated economies), they may have a greater say over the adoption of reforms oriented to encourage social accountability -and, then, more programmatic spending- by reallocating rents province-wide through redistributive fiscal rules. Thus, recent disappointing developmental outcomes at the subnational level, as Arellano-Yanguas (2011) and Ticci and Escobal (2015) have shown in the case of Peru, may be the result of transferring a large fraction of revenues only to subnational governments in the mining areas.

Under what conditions would rational politicians promote the creation of redistributive rent-sharing institutions? We expect this phenomenon more likely to occur at intermediate levels of political competition. In barely competitive and highly fragmented electoral settings, social pressures and political challengers are very weak or extremely conflictive. So that incumbents have strong incentives to centralize mineral rents and spend them discretionarily. In contrast, moderately competitive environments promote non-contentious social pressures and make elections riskier for incumbents. Politicians from both the government and the opposition would, therefore, have more incentives to distribute rents so as to marshal electoral support in contested districts, and have access to those moneys in case they reach power. Further research should assess whether political competitiveness and other factors are conducive to providing the right incentives to design redistributive institutions that properly target the interests of actors involved in the extractive industry. Exploring these issues is crucial to advancing our theoretical understanding of the relation between natural resources and subnational development, particularly in developing countries. 


\section{Bibliography}

Aragón FM, Rud JP. The blessing of natural resources: evidence from a Peruvian gold mine. Banco Central de Peru Working Paper Series 2009; 15.

Arellano-Yanguas, J. Aggravating the resource curse: decentralisation, mining, and conflict in Peru. The J of Dev St 2011; 47 (4): 617-638.

Arellano-Yanguas J. Extractive industries and regional development: lessons from Peru on the limitations of fiscal transfers to producing regions, Unpublished paper 2016.

Auty R. M. Sustaining development in mineral economies: the resource curse thesis. London and New York: Routledge; 1993.

Beblawi H. The rentier state in the Arab world, in Luciani G, editor. The Arab State, Berkeley: University of California Press; 1990, p.49-62.

Beblawi H, Luciani G. The rentier state, nation, state, and integration in the Arab World. London: Croom Helm; 1987.

Beck N. From statistical nuisances to serious modeling: Changing how we think about the analysis of time-series-cross-section data. Political Analysis 2007; 15: 97-100.

Bonvecchi A, Lodola G. The dual logic of intergovernmental transfers: presidents, governors, and the politics of coalition-building in Argentina. Publius: The J of Federalism 2011: 41 (2): 179-206.

Bueno de Mesquita B, Morrow JD, Siverson R, Smith A. The logic of political survival. Cambridge, Mass: MIT Press; 2003.

Cámara Argentina de Empresarios Mineros (CAEM), Minería Argentina, 2015.

Caselli F, Michaels G. Do oil windfalls improve living standards? Evidence from Brazil. Am Econ J: Applied Econ 2013: 5 (1): 208-38. 
Cuenta de Inversión, Gobierno de Neuquén, 2005-2014.

Davis GA, Tilton JE. The resource curse. Nat Res Forum 2005; 29: 233-242.

Diagnóstico Político, Informes sobre Conflictividad Social, Buenos Aires: 2009-2016.

Díaz-Rioseco D. Blessing and curse. Oil and subnational politics in the Argentine provinces. Comp Pol St 2016; 49 (14): 1930-1964.

Dunning T. Crude democracy: natural resource wealth and political regimes. New York: Cambridge University Press; 2008.

Gertler P, Martinez S, Premand P, Rawlings L, Vermeersch C. Impact evaluation in practice. 2nd ed. Washington, DC: The World Bank; 2016.

Gervasoni, C. A rentier theory of subnational regimes: Fiscal federalism, democracy, and authoritarianism in the Argentine provinces. World Pol 2010; 62 (2): 302-340.

Goldberg E, Wibbels E, Mvukiyehe E. Lessons from strange cases: democracy, development, and the resource curse in the US states. Comp Pol St 2008; 41: 477-514.

González LI. Transferencias federales, desigualdad interregional y redistribución, Am Lat Hoy 2014; 67: 167-190.

González LI. Oil rents and patronage: the fiscal effects of oil booms in the Argentine provinces, Comp Pol 2018; 51 (1): 101-126.

Gylfason T, Herbertsson TT. A mixed blessing: natural resources and economic growth. Microec Dynamics 1999; 3: 204-225.

Grzymala-Busse, A. Rebuilding leviathan: party competition and state exploitation in postcommunist democracies, New York: Cambridge University Press; 2007.

Hirschman AO. A generalized linkage approach to development, with special reference to staples. Econ Dev and Cultural Change 1977: 25-67. 
Interamerican Development Bank (IADB)-Fundación YPF. Las Heras Sostenible. Hacia un desarrollo urbano con identidad 2014a.

Interamerican Development Bank (IADB)-Fundación YPF. Añelo Sostenible. Innovación para la Planificación de la Ciudad 2014b.

Instituto Argentino del Petróleo y del Gas (IAPG). Análisis y Proyección de Impactos Económicos Esperados del Desarrollo de los Hidrocarburos No Convencionales en Argentina. Cuantificación de Impactos Económicos del Desarrollo en Escala de Vaca Muerta en la Provincia de Neuquén 2014.

Karl TL. The paradox of plenty: oil booms and petro-states, studies in international political economy. Berkeley: University of California Press; 1997.

Lodola G. Gobierno nacional, gobernadores e intendentes en el kirchnerismo. In: de Luca M, Malamud A, editors. La política en tiempos de los Kirchner. Buenos Aires: Eudeba; 2011. p.217-227.

Luciani G. Allocation vs. production states: a theoretical framework. In: Luciani G, editor. The Arab State. University of California Press; 1990. p.65-84.

Magaloni B, Diaz-Cayeros A, Estévez F. Clientelism and portfolio diversification: a model of electoral investment with applications to Mexico. In: Kitschelt H, Wilkinson SI, editors. Patrons, clients and policies patterns of democratic accountability and political competition. Cambridge: Cambridge University Press; 2007. p.182-205.

Mahdavy H. The patterns and problems of economic development in rentier states: the case of Iran. In: Cook MA, editor. Studies in economic history of the Middle East. London: Oxford University Press; 1970. p.37-61.

Ministerio de Economía, Finanzas e Infraestructura, Provincia de Santa Cruz, 2018. 
Observatorio Económico ACIPAN. Informes sobre conflictividad local, Neuquén: 2013-2017.

Orihuela JC. Institutions and place: bringing context back into the study of the resource curse. J of Institut Econ 2017; 14 (01): 157-180.

Plumper T, Troeger V. Efficient estimation of time-invariant and rarely changing variables in finite sample panel analyses with unit fixed effects. Pol Anal 2007; 15: 124-139.

Postali FAS, Nishijima M. Oil windfalls in Brazil and their long-run social impacts. Res Pol 2013; 38 (1): 94-101.

Postali F, Slaibe A. Petroleum royalties and regional development in Brazil: the economic growth of recipient towns. Resources Pol 2009; 34 (4): 205-213.

Remmer KL. Does foreign aid promote the expansion of government? Am J of Pol Sc 2004; 48 (1): 77-92.

Robinson JA, Torvik R, Verdier T. Political foundations of the resource curse. J of Dev Econ 2006; 79 (2): 447-468.

Rodden J. Strength in numbers? Representation and redistribution in the European Union. Eur Union Pol 2002; 3 (2): 151-175.

Ross ML. The political economy of the resource curse. World Pol 1999; 51 (2): 297-322.

Ross ML. Does oil hinder democracy? World Pol 2001; 53 (3): 325-361.

Ross ML. The oil curse: how petroleum wealth shapes the development of nations. Princeton: Princeton University Press; 2012.

Sachs JD, Warner AM. Natural resource abundance and economic growth. Dev Disc Paper 517a. Cambridge, MA: Harvard Institute for International Development; 1995.

Seawright J, Gerring J. Case selection techniques in case study research: A menu of qualitative and quantitative options. Pol Res Quart 2008; 61 (2): 294-308. 
Snyder R. Scaling down: the subnational comparative method. Stud Comp Int Dev 2001; 36 (1): 93-110.

Ticci E, Escobal J. Extractive industries and local development in the Peruvian Highlands. Environm and Dev Econ 2015; 20 (1): 101-26.

Torvik R. Learning by doing and the Dutch disease. Eur Econ Rev 2001; 45: 285-306.

Toscani FG. The impact of natural resource discoveries in Latin America and the Caribbean: a closer look at the case of Bolivia. Washington DC: International Monetary Fund; 2017.

Van der Ploeg F. Natural resources: curse or blessing? J of Econ Lit 2011; 49 (2): 366-420.

Weitz-Shapiro R. What wins votes: why some politicians opt out of clientelism, Am J of Pol Sc 2012; 56: 568-583.

Wilson SE, Butler DM. A lot more to do: the sensitivity of time-series cross-section analyses to simple alternative specifications. Pol Anal 2007; 15 (2): 101-123.

\section{Acknowledgements:}

Funding for this project was provided by the Targeted Research Projects (Proyectos de Investigación Orientados, PIO) CONICET - YPF 2015-2016, PIP 13320140100022 CO. We conducted fieldwork for this project in the provinces of Neuquén (April 2016), Mendoza (August 2016), Chubut (October 2016), Río Negro (November 2016), Santa Cruz (September 2017), and Tierra del Fuego (December 2017). We thankfully acknowledge the helpful comments of Diego Díaz Rioseco, Kent Eaton, Juan Gutiérrez-Rodríguez, Juan Pablo Luna, Osmel Manzano, Sebastián Mazzuca, José Carlos Orihuela, Richard Snyder, and the 
participants at the XXXVI International Congress of the Latin American Studies Association (LASA), Barcelona, May 22-25, 2018; the Research Seminar Center for Latin American and Caribbean Studies, Watson Institute for International and Public Affairs, Brown University, April 5, 2018; the Workshop on Sub-National Politics in Latin America, Pontificia Universidad Católica de Chile, Santiago, Chile, November 30-December 1, 2017; and the XXXV International Congress of the Latin American Studies Association, Lima, Peru, April 29May 1, 2017. We also thank Belén Cáceres, Rocío Moris, and Julieta Casas who provided crucial research assistance for this project, and the personnel from the provincial ministries and public offices for their interviews and help in getting access to data and information. Any mistake is the sole responsibility of the authors. 